\title{
Role of Subsurface Geo-Energy Pilot and Demonstration Sites in Delivering Net Zero
}

\author{
M. H. Stephenson ${ }^{1,2 \star}$, D. A. C. Manning ${ }^{3}$, M. J. Spence ${ }^{2}$, L. Stalker ${ }^{4}$, Z. K. Shipton ${ }^{5}$ and \\ A. A. Monaghan ${ }^{6}$ \\ ${ }^{1}$ Stephenson Geoscience Consulting, Nottingham, United Kingdom, ${ }^{2}$ British Geological Survey, Nottingham, United Kingdom, \\ ${ }^{3}$ School of Natural and Environmental Sciences, Newcastle University, Newcastle upon Tyne, United Kingdom, ${ }^{4}$ CSIRO, \\ Kensington, WA, Australia, ${ }^{5}$ University of Strathclyde, Glasgow, United Kingdom, ${ }^{6}$ British Geological Survey, The Lyell Centre, \\ Edinburgh, United Kingdom
}

Recent research suggests that the effects of climate change are already tangible, making the requirement for net zero more pressing than ever. New emissions targets have been announced in April 2021 by various governments, including by the United Kingdom, United States, and China, prior to the Conference of the Parties (COP26) in Glasgow. Part of the solution for net zero will be geo-energy technologies in the subsurface, these include: mine water geothermal, aquifer thermal energy storage (ATES), enhanced geothermal systems and other thermal storage options, compressed air energy storage (CAES), and carbon dioxide capture and storage (CCS) including bioenergy CCS (BECCS). Subsurface net zero technologies have been studied by geologists at laboratory scale and with models, but also require testing at greater-than laboratory scale and in representative conditions not reproducible in laboratories and models. Test, pilot and demonstration facilities aid rock characterisation process understanding and up-scaling, and thereby provide a bridge between laboratory testing and computer modelling and full-scale operation. Examples of test sites that have progressed technology development include the Otway International Test Centre (Australia, CCS) and the Äspö Hard Rock Laboratory (Sweden, geological radioactive waste disposal). These sites have provided scale up for key research questions allowing science issues of relevance to regulation, licencing and permitting to be examined at scale in controlled environments. Successful operations at such sites allow research to be seen at first hand to inform the public, regulators, supply chain companies and investors that such technologies can work safely and economically. A Geological Society conference on the "Role of subsurface research labs in delivering net zero" in February 2021 considered the value of test sites and gaps in their capability. Gaps were identified in two areas: 1 ) test facilities to aid the design of low cost, high resolution, unobtrusive seismic and other monitoring for a seismically noisy urban environment with a sensitive human population, for example for ATES in urban areas; and 2) a dedicated through-fault zone test site to understand fault transmissivity and reactivation. Conference participants also recommended investment and development in test sites, shared facilities and risk, joint strategies, data interoperability and international collaboration. 


\section{NEED FOR NET ZERO}

The effects of climate change are already tangible: assessments of melting rates of ice sheets in Greenland and Antarctica match the IPCC's (Intergovernmental Panel on Climate Change) worst-case climate warming scenarios (Slater et al., 2020), parts of the world now see a 1-in-100-year drought happening every two to 5 years (Naumann et al., 2018). Based on current national pledges, and assuming the level of ambition does not change, the world is heading for around $3^{\circ} \mathrm{C}$ of warming by the end of the century (UN Environment Programme, 2019). Globally, a $4^{\circ} \mathrm{C}$ level of warming by the end of the century may result in large scale and irreversible changes to the climate, including large-scale methane release from thawing permafrost and the collapse of the Atlantic Meridional Overturning Circulation (European Commission, 2020). At this temperature, ice sheet loss could result in multi-metre rises in sea level on time scales of a century to millennia (IPCC, 2019).

\section{GEOSCIENCE AND NET ZERO}

Geoscience and subsurface technology have long been understood as part of the solution to decarbonisation. As early as 2004, Pacala and Socolow (2004) highlighted technologies and behavioural changes that could bring about emissions reduction calculated to be of a scale that could bring about measurable change. They visualised $\mathrm{CO}_{2}$ emissions reduction as the "stabilization triangle," the space on a conceptual graph between a "current path" (with rising carbon emissions) and a "flat path" (showing what could be achieved by lowering emissions). The stabilisation triangle was made up of technology-related "wedges" to make the task of decarbonisation more manageable; each wedge being an activity that, if executed alone between now and 2055, could stop a billion tonnes per annum of extra carbon from getting into the atmosphere by 2055 . Several of these wedges had a geoscience aspect including geological disposal of nuclear waste associated with increased low carbon nuclear power generation and the increased supply of gas to allow a switch of power generation from coal to gas in thermal power stations. According to Pacala and Socolow (2004), one of these wedges could be accounted for by carbon capture and storage (CCS), if it was applied to coal power stations totalling $800 \mathrm{GW}$ capacity (about 200 large coal power stations) and $\mathrm{CO}_{2}$ emissions were stored underground.

More recently, the IPCC (2018) described four "illustrative model pathways" to limit global warming to the Paris COP21 $1.5^{\circ} \mathrm{C}$ objective. Pathway P1 involves social, business and technological innovations that result in lower energy demand up to 2050 and rising living standards, especially in the developing world, but involves only afforestation as a method of carbon dioxide removal (CDR). P2 focuses on sustainability and international cooperation, as well as shifts towards sustainable and healthy consumption patterns, lowcarbon technology innovation, and well-managed land systems with limited societal acceptability for bioenergy CCS (BECCS). In P3, societal as well as technological development follows historical patterns and emissions reductions are mainly achieved by changing the way in which energy and products are produced, and to a lesser degree by reductions in demand. In P4, which where there is a slower response to decarbonisation, there is consequently a need for CCS, and more use of negative emissions technology with extensive deployment of BECCS.

The Sustainable Development Scenario of the International Energy Agency's World Energy Outlook (International Energy Agency, 2018) also achieves the long-term objectives of the Paris agreement, and assumes increases in wind and solar energy, expansion of the electric car fleet, increased energy productivity and deployment of carbon capture utilisation and storage (CCUS) technologies. The Energy Transitions Commission (2017) looks more broadly across the finance and policy landscape and sees decarbonisation as being achieved by four transition strategies running simultaneously facilitated by finance and policy enablers. These are 1) decarbonisation of power combined with extended electrification, 2) decarbonisation of activities which cannot be costeffectively electrified, 3) acceleration in the pace of energy productivity improvement, and 4) optimization of fossil fuels use within overall carbon budget constraints. The ETC suggests that decarbonisation of power combined with extended electrification could account for the largest share of emissions reductions between now and 2040 with zero-carbon sources (mainly renewables) accounting for up to $80 \%$ of the global power mix by 2040 .

The ETC's second strategy, involving decarbonisation of activities like transport or industrial activities such as cement or steel manufacture which cannot be electrified at reasonable cost, is more of a technical challenge and requires $\mathrm{CCS}$. The third looks at efficiency improvements in building insulation, household appliances, transport equipment and industrial processes; and the fourth at optimization of fossil fuel use within overall carbon budget constraints.

Decarbonisation can also be seen within the framework of global development and the United Nations Sustainable Development Goals (SDGs), and particularly SDG7: "Ensure access to affordable, reliable, sustainable and modern energy for all." The services that energy, both electrical power, but also heat and light provides, improve human, social, economic and environmental conditions; and final energy use and the Human Development Index (HDI) are correlated (Steckel et al., 2013). SDG7 is therefore intimately connected with most of the other 17 SDGs mainly through providing improved living standards, economic growth and activity, and improved environmental protection. However, a central industrial and social challenge of the 21 st century is to satisfy growing energy demand while reducing emissions related 
to energy production, but also to ensure that energy is available to all (Stephenson, 2018; Stephenson, 2021).

The COVID-19 pandemic has influenced energy demand and consumption. The IEA's Global Energy Review (2021), predicts that global energy demand will increase by $4.6 \%$ in 2021 , more than offsetting the $4 \%$ contraction in 2020 and pushing demand .5\% above 2019 levels. Almost $70 \%$ of the projected increase in global energy demand is in emerging markets and developing economies. The IEA predicts that demand for all fossil fuels is set to grow significantly in 2021 with coal demand rising. Another likely trend that will influence decarbonisation concerns the energy cost of online activity. Data centres already use $1 \%$ of global energy, predominantly for cooling (Masanet et al., 2020; Obringer et al., 2021). As remote and on-line working increases post COVID-19, this component of energy use will increase, and needs to be taken into account in the context of energy demand, access and equity.

\section{Importance of Subsurface Geo-Energy Test Sites}

To achieve emissions reductions, several existing and new geo-energy technologies (Stephenson et al., 2019) will therefore be accelerated and developed including abating emissions from fossil fuel power generation including CCS, BECCS, and direct air capture and storage (DACCS), energy storage for grid stabilisation in a renewable power system (aquifer thermal energy storage, ATES; compressed air energy storage, CAES), and decarbonising heat through district heat networks (geothermal heat, thermal storage). These and other technologies have been studied by geologists at laboratory scale and in models and simulations, but also require testing at pilot and demonstration scale and in representative conditions not reproducible in labs and models.

\section{Main Geoscience Questions in Geo-Energy Technologies}

CCS involves the capture of carbon dioxide $\left(\mathrm{CO}_{2}\right)$ from large point sources, such as chemical plants or steelworks, and then storing it in an underground geological formation (Holloway, 2007; Stephenson, 2013). The chief geological question in CCS relates to long-term predictions about submarine or underground storage security (Phelps et al., 2015). Bioenergy with Carbon Capture and Storage (BECCS) is a variant on CCS that uses biofuels rather than fossil fuels as the source combustion material. The choice of combustion material is crucial because it improves the balance of energy and emissions such that BECCS could result in net "negative emissions" (e.g., Rockström et al., 2017), however the geological questions for BECCS are essentially the same as those for CCS. DACCS, involving direct chemical capture from the air, may involve geological storage (e.g., in basalts, Alfredsson et al., 2013) with similar questions over storage security and longevity.
Shallow and deep geothermal extraction and heat storage may provide a way to decarbonise space heating. The distinction between near surface and deep geothermal extraction and storage systems results from the different geochemical and geomechanical characteristics of geothermal reservoirs at different depths, and the different techniques of utilization (Major et al., 2018; Stober and Bucher, 2021). Deep geothermal systems exploit geothermal energy by means of deep boreholes where thermal energy can be used directly and does not require further transformation. Near surface geothermal systems extract thermal energy from the uppermost layer of the Earth's crust. Typical systems include: ground heat collectors, borehole heat exchangers, boreholes into groundwater, and geothermal energy piles. The exploitation is indirect and requires conversion with, for example heat pumps (Stober and Bucher, 2021). The main geological questions relate to the heat conductivity and specific heat capacity and porosity of deposits (Stober and Bucher, 2021). Enhanced geothermal systems (EGS) use the deep underground as a source of heat for the production of electrical and thermal energy irrespective of the hydraulic properties of the deep heat reservoir through hydraulic stimulation (Stober and Bucher, 2021). Typical target temperatures for EGS systems are above $200^{\circ} \mathrm{C}$. EGS may be associated with induced seismicity (Majer et al., 2007). There is potential for "superhot" geothermal (e.g., in Iceland, Árnason, 2020) at a depth of 2 km immediately above a magma body, producing superheated steam reaching $450^{\circ} \mathrm{C}$. Technical options for subsurface heat storage include aquifer and borehole thermal energy storage, which in principle enable heat storage in most subsurface geological formations. Using temperatures of up to $90^{\circ} \mathrm{C}$ allows an increase in storage rates and capacities. Modelling by Major et al. (2018) found storing $90^{\circ} \mathrm{C}$ water at $2,500 \mathrm{~m}$ depth is capable of reproducing, on average $67 \%$ of the stored energy, but methods for predicting induced thermal, hydraulic, mechanical and chemical effects need to able to assess the environmental impact of storage.

An emerging theme reflecting the imbalance of supply and demand due to renewables" intermittency is "power to gas" where excess renewable electricity is converted through electrolysis of water to combustible gases with high energy density, e.g. hydrogen and synthetic methane. It involves large cheap storage of fuel gases in geological reservoirs and underground caverns (Ma et al., 2018). The range of geological questions in underground gas storage are many and varied reflecting the variety of geological habitats (depths, rock types and potential uses), and are reviewed by Evans et al. (2009) and Evans (2008).

\section{Pilot and Demonstration Plants}

Pilot and demonstration plants (PDPs) represent bridges between generating basic knowledge and technological breakthroughs on the one hand, and industrial applications and commercial adoption on the other (Hellsmark et al., 2016). A pilot plant is defined as a facility that operates discontinuously, partially demonstrates the feasibility of a technology, and is not embedded in the entire value chain. A demonstration plant is defined as a plant that can be operated 


\section{Public sector investment}

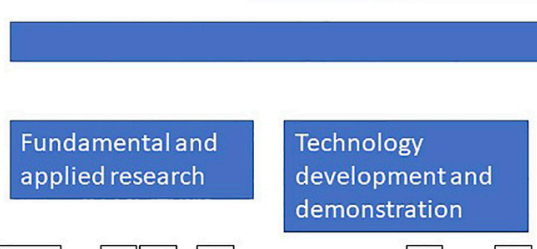

FIGURE 1 | Pilot and demonstration in the context of technology development. TRL = NASA's Technology Readiness Levels.

TABLE 1 | Elements of PDPs and geological factors, adapted from Hellsmark et al. (2016).

Element

Description

\section{Niche markets}

Reaching market

competitiveness
Market penetration

\begin{tabular}{|l||l|l|}
\hline TRL & 2 & 3 \\
\hline
\end{tabular}

development and

\begin{tabular}{|c|c|}
\hline Risk reduction & $\begin{array}{l}\text { New sustainable technology is a highly uncertain process, involvin } \\
\text { technical, market-related, organizational, and institutional risks whe } \\
\text { moving from laboratory to full-scale production }\end{array}$ \\
\hline Learning processes & $\begin{array}{l}\text { Learning is essential for reducing risk, including feedback loops, } \\
\text { cumulative causation and different "motors" for the interaction } \\
\text { among functions. Learning involves generating tacit knowledge } \\
\text { about technical challenges but also about market preferences, } \\
\text { institutional constraints, and the physical infrastructure }\end{array}$ \\
\hline
\end{tabular}

Actors and Agency

Pilot- and demonstration plant (PDP) activities are typically embedded in actor network structures consisting of supply chain, operators and client firms, university researchers, and other private and public actors, which together shape the context for technological development by assuming different roles. The actors are viewed as structural elements on the one hand, but their capacity to take action and assume a critical role in the development process is equally important (i.e., agency)

Network performance and management

Different network characteristics may influence how challenges are addressed, as well as how to govern the evolution of the networks. Because cooperation and learning do not emerge spontaneously, network management, that is, actions taken to advance the interactions in a PDP network, becomes critical

Institutional pre-conditions The efforts to manage networking processes take place within an institutional context of rules and codes of conduct. These will emerge at multiple layers of government and other institutions, and they therefore also encompass sub-national rules. Compared to incumbent technologies, new technological systems often operate in less-developed institutional and organizational settings. It is therefore imperative that technology not only align with existing institutions but also that institutions align with new technology
Examples of geoscience component
Drilling and other capital costs

Liability and risk

Social 'licence to operate'
Geological PDPs have strong commercial industrial, government and academic interests
Networks in geological PDPs involve by necessity different geological specialist communities, communities outside geoscience, e.g. engineering, social science
The development of PDPs involves operating within regulatory environments not necessarily set up for them (for example oil and gas regulatory for geo-energy), but also seeking to influence and improve regulatory environments continuously over an extended period of time; it also demonstrates the entire production process and is embedded in a value chain. PDP investments are often associated with major socio-technical challenges involving significant public support. They also act in the space between 1) public sector investment and private sector investment, and 2) fundamental and applied research and technology development and demonstration (Figure 1). 


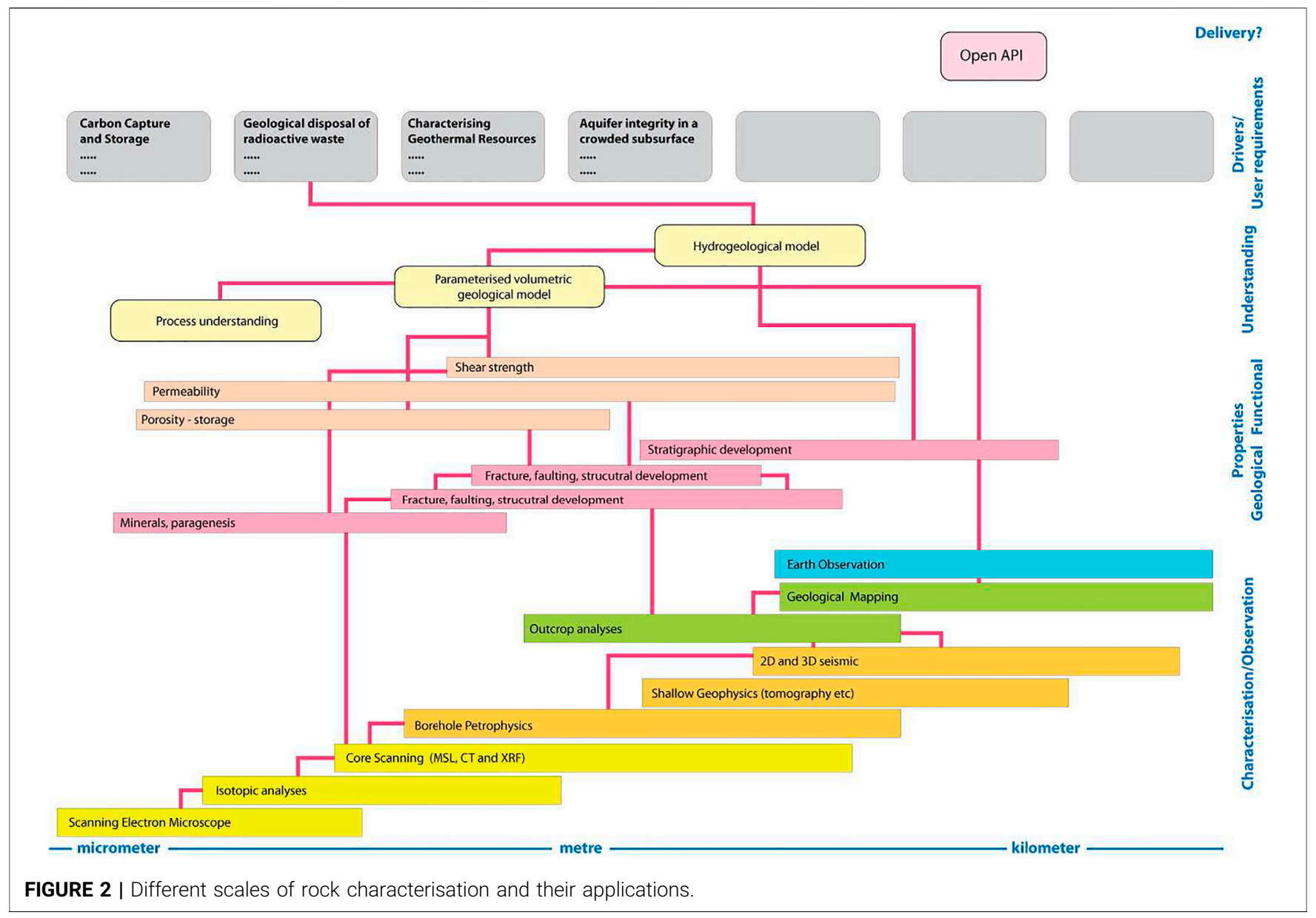

Hellsmark et al. (2016) consider the role of PDPs to be in five areas: risk reduction, learning processes, actors and agency, network performance and management, and institutional preconditions (Table 1).

Though PDPs have been developed in the subsurface for new geo-energy technology such as unconventional gas (e.g., the Marcellus Shale Energy and Environment Laboratory, Morgantown, WV, United States) and CCS (e.g., CO2CRC Otway, Otway, VIC, Australia), the bulk of geo-energy technologies are not supported by PDPs that provide insight into the full range of possible geological conditions and variability in which demonstration scale, commercial- or fullscale operations might take place. Those geological conditions require better understanding of rock heterogeneity, fluid flow, and geomechanical and geochemical change, as well as real time monitoring of subsurface changes. Geologists have by and large approached these geological challenges through laboratory scale experiments, simulation and modelling. One factor that has held back the realisation of technologies is the ability to "upscale" between laboratory scale and full operational or commercial scale, as well as the connected problem of the "valley of death" where the absence of a business model prevents implementation (Downey, 2012).
It was realisation of the importance that geo-energy PDPs could play in delivering geological solutions to net zero that prompted the Geological Society conference "The role of subsurface research labs in delivering net zero," which was convened in February 2021. The purpose of the conference was to gather the community of geoscience test sites together to consider 1) the value of PDPs, 2) where they work well to answer questions, and 3) where there are gaps in capability. This paper summarises some of the findings of the conference.

\section{Key Geoscience Questions for Test Sites}

A number of scientific challenges are common to geological decarbonisation technologies. Perhaps the most fundamental of these is the need to characterise rock geochemically and geomechanically (Stephenson et al., 2019). Rock characterisation requires systematic gathering of data from the micrometre to kilometre scale, for example scanning electron microscope studies, isotopic analyses, core scanning, borehole petrophysics, shallow geophysics (e.g., electrical resistivity tomography), 2D and 3D seismic, geological mapping and Earth observation (Figure 2). These contribute to understanding of mineral paragenesis, fracture and faulting development, stratigraphy, permeability, porosity, 
shear strength; and thence to process understanding, models and direct implementation in technology development, for example, geothermal and radioactive waste disposal.

Each of these subsurface technologies comprises several steps in the technology chain:

- characterisation of the resource be it pore space available for disposal or heat resource in place. This is usually achieved through a combination of remote sensing (e.g., geophysical tools) and direct access (boreholes, core and well log data);

- accessing the subsurface through drilling or tunnelling techniques. This includes completion techniques to ensure borehole or tunnel stability and longevity for the lifetime of the resource; safety/resilience of any monitoring tools, infrastructure-and in the case of tunnels-human operators within the subsurface infrastructure; and measures to ensure safety of overlying aquifers or other geological resources;

- safe, efficient and environmentally sustainable operation of the facility; and

- decommissioning.

Each stage of these subsurface operations requires process understanding of the past. present and future behaviour of the rock mass and its interaction with the industrial processes at play: injection, extraction or cycling of fluids for example. In the case of radioactive waste disposal this requires process understanding of the engineered barrier systems and the rock mass for hundreds of thousands of years. At each step monitoring tools require process understanding of the measurands and the likely performance of the tools under subsurface conditions. So PDPs provide the key at-scale process understanding and testing ground for these monitoring tools. PDPs also provide an arena where remediation techniques can be trialled and refined.

In the case of permanent storage of $\mathrm{CO}_{2}$, a combination of core data, wireline log data and seismic image data will be required to characterize subsurface reservoirs, and form the basis for economic decisions on how to use those subsurface stores. This will need strategic investment and a realisation that aspects of decarbonisation will take place in geographical clusters and development corridors where geological and infrastructure conditions are most suited (Stephenson et al., 2019).

For a hydrogen economy, where hydrogen will provide a fuel for cells to drive vehicles, heat houses and power industry, it is likely that large-scale hydrogen storage will be required either from electrolysis of water using excess (renewable) electricity, or in the shorter term by steam methane reforming from natural gas which produces $\mathrm{CO}_{2}$ and hydrogen. While hydrogen from electrolysis provides a low-carbon fuel, hydrogen from natural gas reforming can offer significant scale-up potential for a fledgling industry, but requires the $\mathrm{CO}_{2}$ by-product to be disposed of geologically to mitigate emissions, as in CCS. Deep rock-salt will be used to store hydrogen as part of a large-scale regional hydrogen fuel and heating system where present, but other formations may need to be evaluated where evaporites are absent.

An example is the H21 Leeds City Gate project (Leeds City Gate, 2019) which seeks to convert the existing natural gas network in the UK city of Leeds-used mainly for heat-to hydrogen. A batch of four steam methane reformers on Teeside will produce the hydrogen needed, while the waste $\mathrm{CO}_{2}$ will be captured and disposed of offshore below the southern North Sea. Salt cavern storage in the Tees and York areas will be needed for "intra-day" and "intraseasonal" swings in demand as heating is turned on and off by consumers. One research question relates to the repeated pressurisation and depressurization that salt will be subject to during storage and its ability as a material to contain hydrogen safely, another relates to the scale of hydrogen storage (size and number of caverns) and the associated geological and engineering factors.

Similarly, the geochemical and geomechanical character of other rock formations from unconsolidated sediment, to sedimentary, metamorphic and igneous rocks, needs to be researched to understand the performance of these materials in hosting dynamic energy-related systems such as lowenthalpy geothermal reservoirs or "hot-dry-rock" reservoirs, and tunnelling for pumped storage construction.

Challenges relating to accessing the subsurface principally lie in the need to reduce risk. An example is in drilling and tunnelling technologies where new net zero applications of geological engineering will be run on a different commercial basis to traditional resource extraction, so reducing drilling and tunnelling costs and/or de-risking the subsurface infrastructure is required to ensure that these projects are commercially viable. The cost of decommissioning needs to be built in to such commercial models. The concept of "design for decommissioning" is increasingly being used in industry in recognition of the legacy left by lack of consideration of decommissioning costs.

Another common challenge is the need to understand better the flow of fluids in the deep subsurface, whether they be warm or hot water, steam, carbon dioxide, natural gas or hydrogen. This is not a trivial task given the presence in the subsurface of several fluid phases, reactive rock, fractures and rock heterogeneity. Flow is important because in technologies like geothermal the flow of useful fluids (hot or warm water) is encouraged, while in other technologies fluid containment is paramount, such as in carbon dioxide storage or radioactive waste disposal. An ability to monitor and verify the subsurface through sophisticated imaging and measuring will also be needed.

A final challenge, perhaps recognised as the most pressing, is to understand public attitudes to subsurface decarbonisation technologies. Research has been done on the way that the public view carbon capture and storage, but there are few studies of technologies such as compressed air energy storage or hydrogen storage that show to stakeholders and the public how these new technologies might function, the footprint of their surface infrastructure and any additional environmental or cost 
TABLE 2 | Survey of geological PDPs in geo-energy.

Test site name

Otway CO2CRC project

\begin{tabular}{ll} 
& eastern Australia \\
\hline Hellisheidi & Iceland
\end{tabular}

\begin{tabular}{ll}
\hline Aquistore & SE Saskatchew \\
\hline $\begin{array}{l}\text { National Energy Technology } \\
\text { Laboratory }\end{array}$ & United States
\end{tabular}

Laboratory

Marcellus Shale Energy and West Virginia

Environment Laboratory

Location

Main purpose

Ownership/business model

Otway focusses entirely on carbon capture and storage, and monitoring

A pilot direct air capture facility which captures 50 tonnes of carbon dioxide each year and injects it into basalt reservoirs

Canada's first deep saline carbon dioxide storage project linked to SaskPower's Boundary Dam Integrated CCS Demonstration Project

SaskPower's Boundary Dam Integrated cCS Demonstration Project

Various facilities. Recently NETL has undertaken a major field-based study on fracture growth and gas/fluid migration, during hydraulic fracturing of 6 horizontal Marcellus Shale Gas Wells

Undertaken by the Universities of West Virginia and Ohio, and Northeast Natural Energy, a local shale gas producer, MSEEL is developing its research at a dedicated field site and laboratory in the Marcellus shale gas production region of West Virginia

Meuse/Haute-Marne $\quad$ France

Andra currently operates the Meuse/Haute-Marne radioactive waste underground research laboratory situated $490 \mathrm{~m}$ underground in argillaceous rock at Bure in the Meuse Department

Ketzin Germany

The site has been run by the German Research Centre for Geosciences (Deutsches GeoForschungsZentrum; GFZ). The site has five boreholes drilled for the testing of $\mathrm{CO}_{2}$ injection into potential storage layers

Compostilla Project, Hontomin Spain

The Hontomin site is being considered as a potential deep $\mathrm{CO}_{2}$ store with the target being Lower Jurassic carbonates at depths of $>1,200 \mathrm{~m}$

Boulby Underground laboratory United Kingdom Frio Brine Pilot site Texas US Development of techniques for deep 3D geological monitoring The Frio Brine pilot experiment is a CCS study based near Dayton, Texas. Injection of $\mathrm{CO}_{2}$ at a depth of over $1,500 \mathrm{~m}$

SOTACARBO, Sulcis, Sardina Sardinia Italy

SOTACARBO (Società Tecnologie Avanzate Carbone SpA) is managing a CCS program co-funded by the Italian National Agency for New Technologies, Energy and Sustainable Economic Development (ENEA) and the regional government of Sardinia

$\mathrm{K} 12 \mathrm{~B}$ North Sea, Netherlands K12-B gas field is located in the Dutch Sector of the North Sea. K12$\mathrm{B}$ has been producing gas since 1987. The produced gas has a relatively high $\mathrm{CO}_{2}$ content that was originally vented into the atmosphere. Recently this $\mathrm{CO}_{2}$ component has been separated and injected back into the reservoir rocks

\begin{tabular}{|c|c|c|c|}
\hline Snøhvit & Norway & $\begin{array}{l}\text { Three gas fields: Snøhvit, Albatross and Askeladd where waste } \mathrm{CO}_{2} \\
\text { is re-injected. The fields are located in the Barents Sea situated } \\
\sim 140 \mathrm{~km} \text { northwest of Hammerfest }\end{array}$ & Commercial \\
\hline Avalon Borehole Test Facility & United Kingdom & $\begin{array}{l}\text { Used to test, and prove, borehole equipment in a controlled } \\
\text { environment }\end{array}$ & Commercial \\
\hline Schlumberger Training Centre & United Kingdom & $\begin{array}{l}\text { Provides training courses in the practical and theoretical aspects of } \\
\text { wireline logging data acquisition and applications }\end{array}$ & Commercial \\
\hline Sleipner $\mathrm{CO}_{2}$ injection & Norway & $\begin{array}{l}\text { World's first commercial } \mathrm{CO}_{2} \text { storage project. Situated in the } \\
\text { Norwegian sector of the North Sea near the United Kingdom } \\
\text { boundary. } \mathrm{CO}_{2} \text { injection and storage is within the Utsira Formation; a } \\
\text { saline reservoir situated }>800 \mathrm{~m} \text { below the seabed }\end{array}$ & Commercial \\
\hline UKGEOS Glasgow & United Kingdom & $\begin{array}{l}\text { Network of } 12 \text { boreholes designed to observe how warm water } \\
\text { moves around abandoned mine workings and to monitor changes in } \\
\text { the chemistry, physical and microbiological properties of the } \\
\text { environment following heat storage or extraction }\end{array}$ & Government \\
\hline Bochum & Germany & Thermal storage in an abandoned coal mine & $\begin{array}{c}\text { Public-Private partnership } \\
\text { (Continued on following page) }\end{array}$ \\
\hline
\end{tabular}

Academic commercial consortium

Government

Government

Commercial

Government

Government academic consortium

Government

Government

nt

Public-Private partnership

Public-Private partnership

Commercial

Government

( 
TABLE 2 I (Continued) Survey of geological PDPs in geo-energy.

\begin{tabular}{|c|c|c|c|}
\hline Test site name & Location & Main purpose & Ownership/business model \\
\hline Geo-energy Test bed & Nottingham, United Kingdom & $\begin{array}{l}\text { Deep and shallow injection wells for monitoring the motion of gases } \\
\text { and liquids through natural pathways in the subsurface after } \\
\text { injection }\end{array}$ & $\begin{array}{l}\text { Government-academic } \\
\text { consortium }\end{array}$ \\
\hline Cardiff Urban Geo Observatory & United Kingdom & Shallow geothermal heat recovery and storage & Government \\
\hline Äspö Hard Rock Laboratory & Sweden & $\begin{array}{l}\text { Facility for research into disposal of radioactive waste situated north } \\
\text { of Oskarshamn (Sweden) }\end{array}$ & Government \\
\hline Grimsel Test Site & Switzerland & Facility for research into disposal of radioactive waste & Government \\
\hline Mont Terri & Switzerland & Facility for research into disposal of radioactive waste & Government \\
\hline Soulz sous Forêts & France & $\begin{array}{l}\text { Facility for the development of geothermal energy for electrical } \\
\text { production }\end{array}$ & Government \\
\hline Krafla Magma test bed & Iceland & Superhot geothermal systems & $\begin{array}{l}\text { Government-academic } \\
\text { consortium }\end{array}$ \\
\hline Basel & Switzerland & Enhanced geothermal & Government \\
\hline Groß Schönebeck & Germany & $\begin{array}{l}\text { Abandoned gas exploration well re-openend by } \\
\text { GeoForschungsZentrum (GFZ), Potsdam and deepened to 4,300 m } \\
\text { for geothermal research }\end{array}$ & Government \\
\hline
\end{tabular}

impacts, including lifecycle emissions (McCay et al., 2019). In densely populated countries in Europe and elsewhere it is clear that very high levels of environmental assurance will be needed to gain a social licence to operate.

\section{FUNCTIONING TEST SITES AND THEIR BENEFITS}

A non-exhaustive survey of geological PDPs in geo-energy is shown in Table 2. These range from direct air capture of $\mathrm{CO}_{2}$ and basalt sequestration (Hellisheidi, Iceland), to $\mathrm{CO}_{2}$ sequestration in deep saline aquifers (Aquistore), to shale gas (Marcellus Shale Energy and Environment Laboratory), to nuclear waste disposal (Äspö Hard Rock Laboratory), to Superhot geothermal systems (Krafla Magma test bed), and to enhanced geothermal (Basel). In this section, a selection of PDPs in CCS, radioactive waste disposal and coal mine energy featured at the Geological Society conference, and that already function, are described including their benefits to the technology they research, as well as wider benefits.

\section{Otway International Test Centre (CO2CRC Otway Project) for Geological $\mathrm{CO}_{2}$ Storage}

Carbon Capture and Storage (CCS) has been identified as a vital technology for climate mitigation. The IPCC, IEA and the UK's Committee on Climate Change (CCC) agree that the targets for greenhouse gas emissions, set out in the Paris Agreement, cannot be met without CCS (e.g., Climate Change Committee, 2018). UK net-zero scenarios involve aggregate annual capture and storage of $75-175 \mathrm{MtCO}_{2}$ in 2050, which would require a major $\mathrm{CO}_{2}$ transport and storage infrastructure servicing at least five industrial clusters and with some $\mathrm{CO}_{2}$ transported by ships or heavy goods vehicles. Industries such as steel, cement, refining chemicals, glass and ceramics all emit $\mathrm{CO}_{2}$ as part of a chemical process required in production. Currently, CCS is the only technology that enables deep decarbonisation for these industries (UKCCS Research Centre website, 2021).

The Otway International Test Centre, Otway, VIC, Australia, is one of the few research CCS test sites in the world. It was established in 2003 by the Cooperative Research Centre for Greenhouse Gas Technologies (CO2CRC) (Cook, 2014). The site is located at the Naylor depleted natural gas field and has the advantage of a local supply of $\mathrm{CO}_{2}$ rich methane from the adjacent Buttress field. CO2CRC have carried out a series of experiments for at-scale geological $\mathrm{CO}_{2}$ storage including measurement, monitoring and verification of the site and its research activities. The development of the site took place in three stages.

Stage 1 involved characterisation of the Naylor field, including 1) design and deployment of a unique bottomholeassembly for in-reservoir monitoring, 2) drilling of an injection well and 3) design of a test that showed how $\mathrm{CO}_{2}$ would interact with the co-existing natural gas in the field itself (Figure 3). The monitoring program covered atmospheric, soil gas, groundwater, in-reservoir sampling and geophysical monitoring. This monitoring has continued until present, after 65,000 tonnes of gas was injected in 2007-2008.

Stage 2 involved a series of activities optimising the drilling of a well into a saline aquifer; a push-pull test to understand and quantify residual $\mathrm{CO}_{2}$ saturation; and a geophysical evaluation of how rapidly plume stabilisation occurs after injection ceases. Stage 3 is presently underway, drilling new 

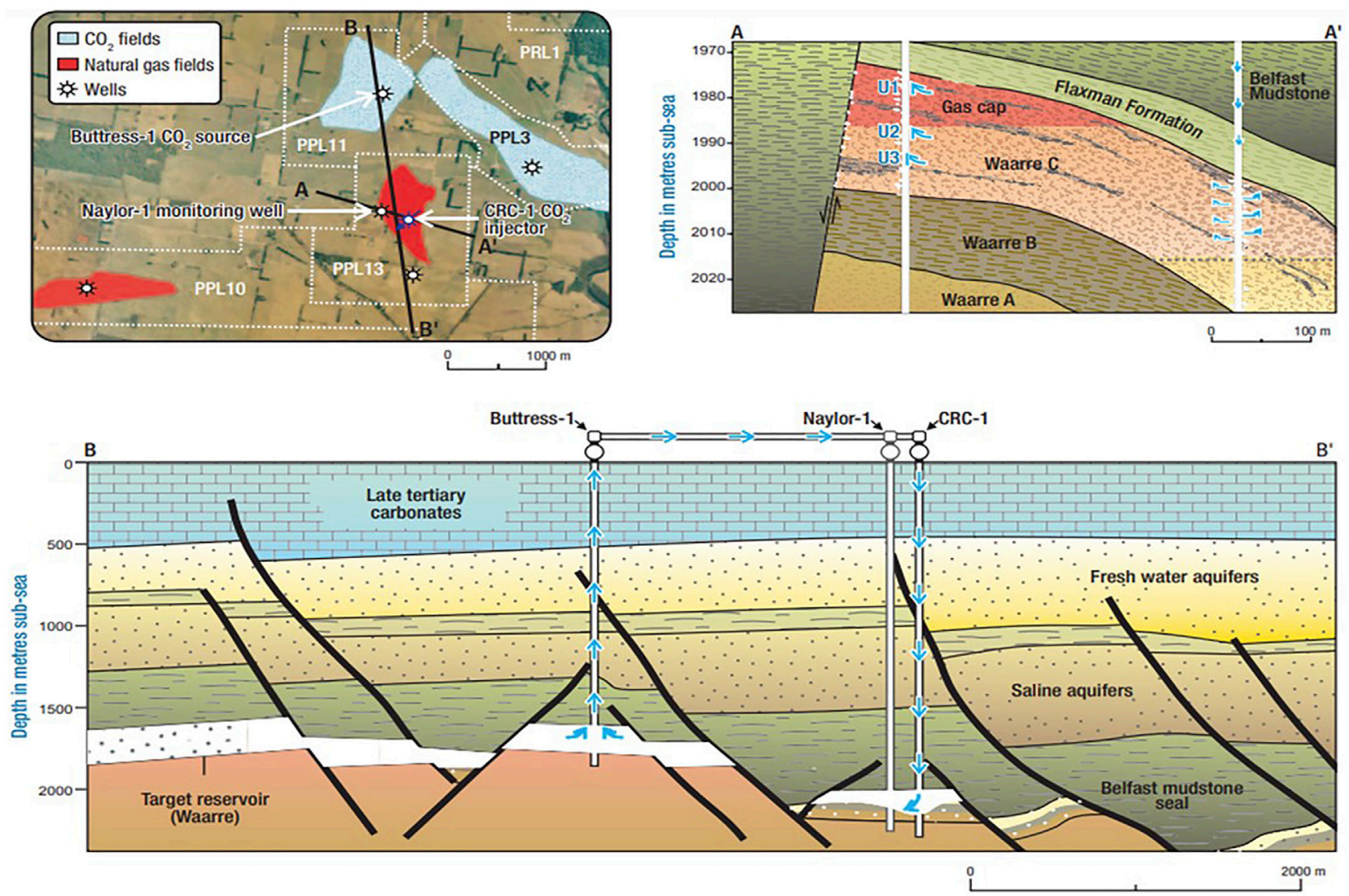

FIGURE 3 | The geology and research infrastructure of the first stage of the Otway test site: North-south cross-section through the faultbound $\mathrm{CO}_{2}$ source and sink intervals overlaying seals and aquifers (modified from Jenkins et al., 2012).

wells and developing new tests to minimise invasive monitoring methods through geophysical activities and tomography. Research in all three stages has resulted in significant advances in CCS technology.

Throughout its development, the Otway site has been open to visitors, including academia, industry, government, and the public, to observe and contribute to the design and development of tests, testing and validating new monitoring tools and pushing advances in CCS research to support Australian and international commercial developments. Research has also been widely communicated in highly cited peer reviewed publications (e.g., Jenkins et al., 2012; Paterson et al., 2013; Bickle et al., 2020). Other publications (e.g., Cook, 2014) provide insight into the establishment of the test facility and the regulation hurdles overcome to develop the site.

In addition to research into the feasibility of CCS carried out at Otway, the development of the site also provides insights into the management of test sites including developing the correct corporate structure and governance to ensure management of liability and uncertainty in project development and science outcomes (Cook, 2014). The site has also developed methods to involve governments in the formation of the statutory and regulatory frameworks necessary for CCS, and perhaps more importantly provided a practical example to local communities of a successful application of the technology which has enhanced community acceptance and even instilled a local sense of pride in the research being done at the facility. It is recognised that test sites need to be firmly embedded in local and regional geological conditions because only then are the full range of geological variables catered for; but also it is recognised that community acceptance of technology is more likely when it can be shown to work locally (Cook, 2014), and when local people can see the research at first hand. For collaborating industry, the benefits include access to next generation technology, provision of a role in the development of regulation of a new technology, public acceptance and cost savings. For industry, CO2CRC's research into the management of long-term liability has been particularly useful: modelling the behaviour of the $\mathrm{CO}_{2}$ plume over a 1,000 year period after injection ceases, allows understanding of long term risk for investors and government regulators.

\section{Rock Laboratories in Deep Radioactive Waste Geological Disposal}

Nuclear energy is widely considered to be a contributor to low-carbon power production, and nuclear power plants the 


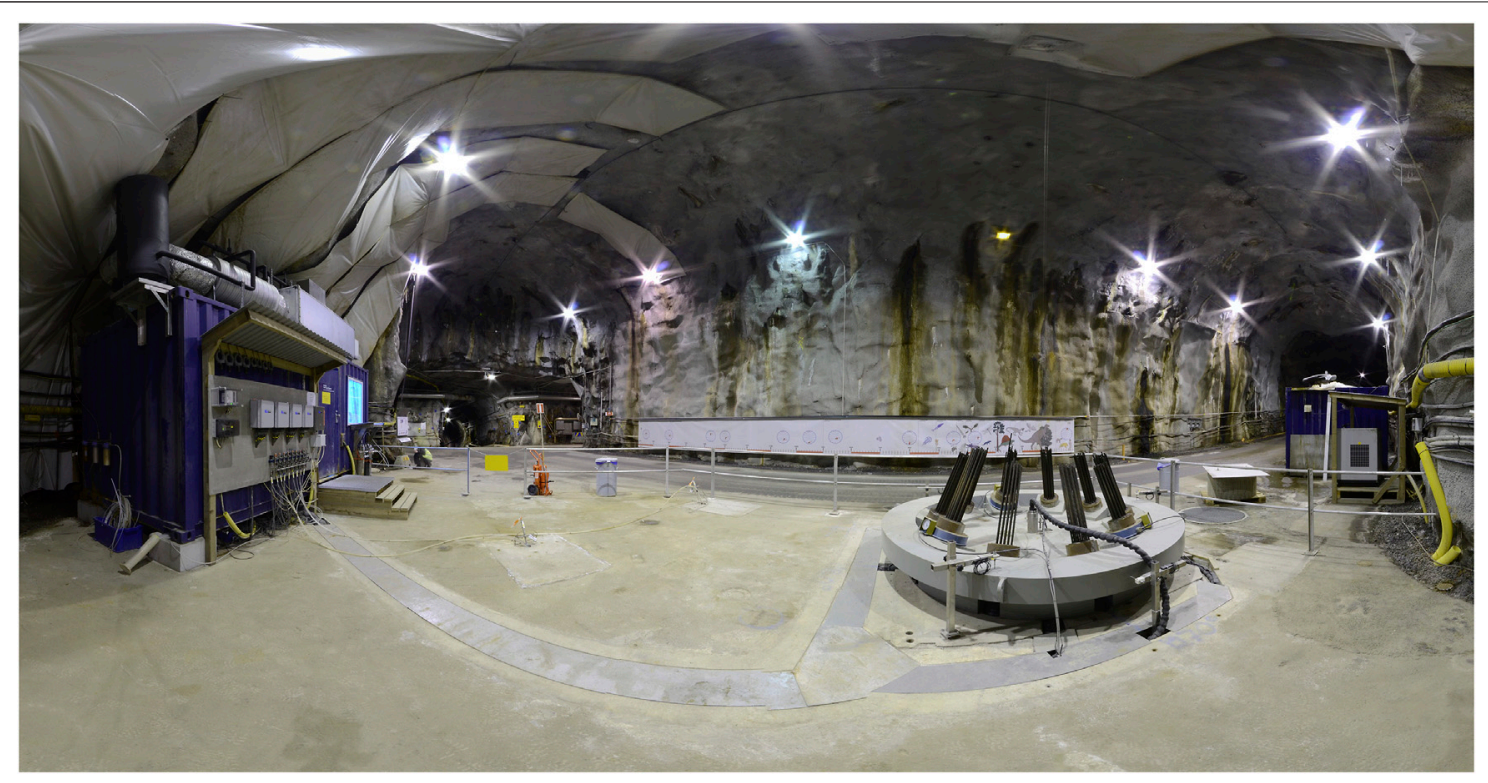

FIGURE 4 | Large scale gas injection test (LASGIT), Äspö Hard Rock Laboratory, Sweden (courtesy of J. Harrington, BGS).

world over have produced useful power, but also radioactive waste. The United Kingdom, for example, has accumulated a substantial legacy of radioactive waste since the 1940s and will continue to do so for many years into the future. By 2,100, it is likely that in the United Kingdom 2.6 million tonnes of high-level radioactive waste will need to be safely managed, probably within deep caverns constructed specifically for the purpose (McEvoy et al., 2016). Essentially, a geological disposal facility (GDF) makes use of engineered materials and structures, including concrete, metals and clays, as well as the surrounding geological environment, as containment barriers. A big part of containment is the natural arrangement of the rocks that surround the engineered barriers. In many ways this is no different from underground disposal or containment of $\mathrm{CO}_{2}$, for example; however, radionuclides may be hazardous for up to a million years into the future. Thus a fundamental requirement of the geological environment is that its behaviour should be predictable enough to establish very long-term radiological safety. Amongst the factors that need to be assessed are present and future seismic activity, glaciation, uplift and erosion, climate change including sea-level rise, isostasy, and permafrost formation-because all of these processes could compromise the performance of the engineered barriers within a GDF (McEvoy et al., 2016). An assessment of risk involves detailed study of geological processes occurring now and in the recent past in order to understand changes up to 1 million years into the future.

Underground rock laboratories (URL) have been used extensively by radioactive waste management organisations around the world to study these geological processes in order to test the feasibility of deep geological disposal solutions. Examples of specific geological challenges include the processes and time scales of self-sealing of fractures in clay rocks, and comparing models of waste canister or bentonite buffer performance against real performance in test conditions. An example of URL work in the latter aspect of radioactive waste science are large scale gas injection tests e.g., LASGIT (Cuss et al., 2011; Figure 4) where very long term experiments, which are unlikely to be feasible for laboratories in institutes or universities, are carried out.

LASGIT was designed to test part of the Swedish KBS-3 radioactive waste repository concept, where copper and steel canisters containing spent nuclear fuel will be placed in large diameter $(\sim 1.8 \mathrm{~m})$ boreholes drilled into the floor of repository tunnels. The space around each canister will be filled with precompacted bentonite blocks, which over time, will draw in the surrounding groundwater and swell, closing up any remaining construction gaps. While the copper/steel canisters are expected to have a very substantial life, it is important to consider the possible impact of groundwater penetrating a canister. Under certain conditions corrosion of the steel insert of each canister will lead to the formation of hydrogen. Radioactive decay of the waste and the radiolysis of water will produce some additional gas. Depending on the gas production rate and the rate of diffusion of gas molecules in the pores of the bentonite, it is possible that gas will accumulate in the void-space of each canister. Recent laboratory work has highlighted a number of uncertainties, notably the sensitivity of the gas migration process to experimental boundary conditions and possible scaledependency of the measured responses.

These issues have been addressed at the LASGIT full-scale demonstration experiment operated by SKB at the Äspö Hard Rock Laboratory at a depth of $420 \mathrm{~m}$. The objective of LASGIT is to provide quantitative data to improve process understanding and to test and validate modelling approaches which might be used in performance 


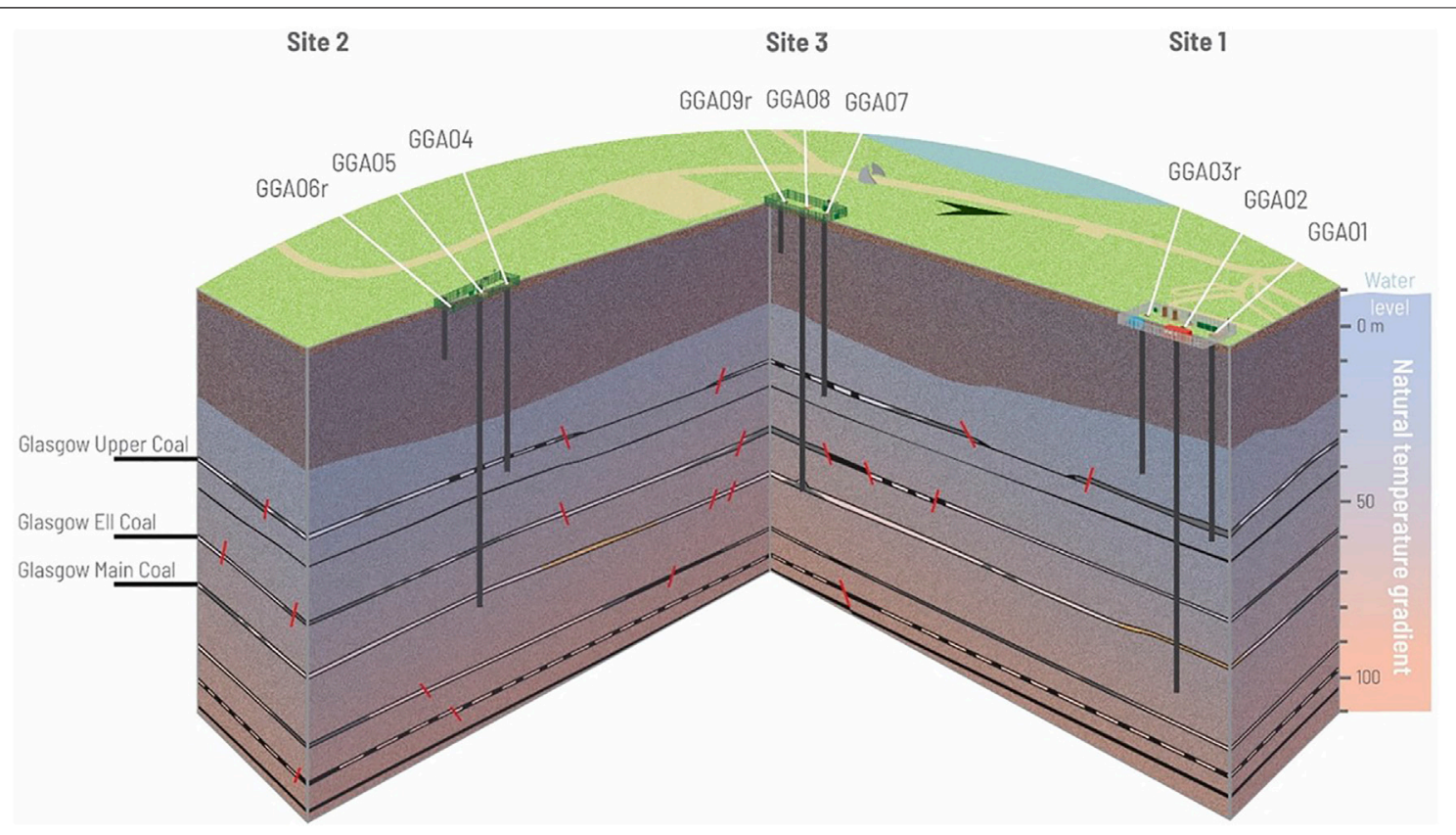

FIGURE 5 | 3D block image showing nine of the Glasgow Observatory boreholes in a triangular arrangement at Cuningar Loop, UK. GGA01, GGA04 and GGA07 are screened in the Glasgow Upper mine working and GGA05 and GGA08 in the Glasgow Main mine working. Depth scale on right hand side in metres relative to Ordnance Datum, no vertical exaggeration. Darker grey are superficial deposits.

assessment. In the 15 years of its operation, LASGIT has produced a large number of peer-reviewed papers, e.g., Graham et al. (2012) and Cuss et al. (2014). Outputs from the test have confirmed early laboratory results on gas migration behaviour in relation to porewater and swelling pressures and dilatational pathways in bentonite. The research has allowed SKB to answer criticisms by the Swedish nuclear regulator of its treatment of gas in its KBS3 concept.

\section{Mine Water Thermal Energy}

Central to achieving our Net Zero target will be the decarbonisation of heating. Using the shallow subsurface for heating, cooling and thermal storage offers a potentially sustainable low carbon solution. With many towns and cities in Britain located upon disused coalfields, there exist significant opportunities to utilise the warm water in abandoned, flooded coal mines for shallow geothermal energy (e.g., Banks et al., 2017; Harnmeijer et al., 2017; Brabham et al., 2019; Farr et al., 2016; Farr et al., 2020).

Commercial mine water schemes attest to the possibilities for heat recovery and storage (e.g., Verhoeven et al., 2014; Loredo et al., 2016; Banks et al., 2017; Lanchester Wines website, 2021), however capital costs and technical risks are barriers to widespread development (e.g., Townsend et al., 2020). Challenges include hydrogeology and hydrochemistry of the resource and environmental impacts (Banks et al., 2009; Burnside et al., 2016a; Burnside et al., 2016b), stability of mine workings (Todd et al., 2019) and efficient, sustainable engineering and heat extraction. Other issues include ownership of heat (Abesser et al., 2018) and development of regulatory and licensing frameworks (Preene and Younger, 2014; Stephenson et al., 2019).

The UK Geoenergy Observatories (UKGEOS), Glasgow Observatory was established between 2016 and 2020 as an at-scale infrastructure for mine water heat and heat storage research in a representative urban setting (Monaghan et al., 2017a; Monaghan et al., 2019; Monaghan et al., 2021). It comprises 12 boreholes, four research compounds, surface monitoring equipment and open data. At Cuningar Loop, the boreholes are arranged in a triangle to characterise depth and spatial variability in 3D over 10-100 sm (Figure 5). Six of the boreholes targeted mine workings at around $50 \mathrm{~m}$ or $85 \mathrm{~m}$. Five are successfully installed with downhole temperature and electrical sensing cables and hydrogeology data loggers to characterise physical and chemical properties. There are five environmental baseline monitoring boreholes drilled to 16-45 $\mathrm{m}$ to record environmental change, any impacts from pumping mine water and to give an opportunity for developing new monitoring technologies. A $199 \mathrm{~m}$ deep borehole provided a cored reference section and is used for seismic monitoring, part of a suite of environmental monitoring equipment and surveys. Finally, additional research capability for heating or cooling perturbations will be provided by a sealed, open loop and heat centre planned to be installed in early 2022 .

The Glasgow Observatory is growing the evidence base on how to transfer heat sustainably and economically at-scale, through time, and in unprecedented detail, as well as monitoring and managing any wider impacts of subsurface change. 


\section{HOW DO GEO-ENERGY TEST SITES HELP IN THE DEVELOPMENT OF REGULATION?}

The development and operation of geo-energy technologies will be controlled through regulation, licencing and permitting. In general, regulations allow activities to happen, while at the same time protecting the environment, property and people. Licences and permits are issued on the understanding that regulations will be followed. Appropriate regulation for subsurface technology will involve understanding the activities and their consequences thoroughly and will neither suppress innovation and appropriate experimentation nor allow unsustainable and damaging practices.

Griffioen et al. (2014) discussed some of the regulatory and policy issues arising from the use of the subsurface in low carbon technology. These take into account the physical and biogeochemical properties of the subsurface in relation to its potential use, and where technical measures can be made to optimise its use. Duration is also important since technology may appropriate the subsurface or some part of it for a period, and following that period it will need to be returned to the condition as before. The use will have to be optimised in the sense that subsurface uses will mutually interact and affect the surface environment, and economic and other human activities. Thus a trade-off between ecosystem services may be required, and consideration of scarcity and sterilisation of useful resources by application of technology. Regulation may in the future require considerations of spatial planning, option assessment, precaution, transparency, responsibility and liability (Griffioen et al., 2014; Monaghan, 2017b; Loveless et al., 2018). Engaging with regulatory bodies and Government in the early stages of research will help in the translation and adoption of research findings for end users. Clearly defined regulations and legislation also enable industry to reach decisions on financial investment that can be uncertain in the absence of regulatory environments.

This regulatory deficit can be perceived by industry as a major risk to investment; not all jurisdictions have relevant regulation for various low emissions activities. In Australia, offshore geological storage regulations are in place (The Commonwealth Offshore Petroleum and Greenhouse Gas Storage Act, 2006), but not for onshore in every state. For example, in Western Australia the Petroleum and Geothermal Energy Resources Act (1967) has no provision for $\mathrm{CO}_{2}$ injection onshore but refers to the Barrow Island Act (2003) as the mechanism allowing $\mathrm{CO}_{2}$ storage for Chevron's Gorgon Gas Field. Victoria, by contrast has established regulations to enable the CarbonNet project to develop. This is a project that straddles physical boundaries between State and Federal waters and managed through Victorian Greenhouse Gas Geological Sequestration Act (2008) and Victorian Offshore Petroleum and Greenhouse Gas Storage Act (2010) and the earlier mentioned Commonwealth Offshore Petroleum and Greenhouse Gas Storage Act (2006). At a global level, in 2018 the vast majority of countries $(<10)$ had no CCSspecific or relevant laws that could facilitate the whole project lifecycle for a CCS development (Havercroft and Consoli, 2018).

At present in the United Kingdom, the two main uses of the subsurface in our energy systems are for the extraction of fossil hydrocarbons and for management and maintenance of utility infrastructure and related underground assets. Other subsurface energy opportunities such as wider use of geothermal will require careful development of regulations, probably modifications of existing groundwater regulation. In geothermal, one of the key challenges in the United Kingdom is that geothermal heat is regarded as a physical property, not a recoverable (raw) material such as ore or gravel (Abesser et al., 2018). As such, "heat" is not a legally-defined entity and this causes some difficulties for legal ownership and regulation. In other parts of Europe, geothermal heat is defined as a natural resource with clear rules of ownership and regulations similar to those for metals and fossil fuels. Research at test sites provides a unique opportunity to investigate the entire lifespan of subsurface projects. This extends from concept and planning through to decommissioning, and includes investigating: 1) construction in the surface to subsurface and research into land use change; 2) operation including perturbations of the subsurface and research into the changing subsurface; 3) decommissioning including provision, effectiveness, cost and innovation; and 4) legacy including construction with a factored-in sustainable end-plan.

Geo-energy subsurface PDPs have a unique role in providing a bridge between lab and modelling and larger scale commercial or demonstration facilities, allowing science issues of relevance to regulation, licencing and permitting to be examined at scale in controlled environments. An example is the way that the Otway project worked with regulators to examine liability associated with long-term storage of sequestered $\mathrm{CO}_{2}$. No statutory regulations previously existed to define the boundaries of compliance. Oil and gas companies routinely take on liability arising from oil and gas subsurface projects, but sequestered $\mathrm{CO}_{2}$ is assumed to be stored indefinitely, and the company carrying out the sequestration process is unlikely to still be in existence over comparable time frames. Test sites like Otway have helped to answer science questions relevant to forming the right regulatory environment to deal with long term liability, for example research into longterm geochemical trapping of $\mathrm{CO}_{2}$ (e.g., Jenkins et al., 2012). The right regulations will simultaneously encourage investment and technology development, while at the same time will manifestly protect the environment and livelihoods.

In geothermal, heat, although not a substance in the physical sense, behaves like groundwater and is regulated in a similar fashion in the United Kingdom, considering impacts and interactions with existing surface water bodies and existing abstractions or discharges. However heat is not licensed in the United Kingdom, causing problems for developers in protecting their investments. It is envisaged that PDPs (e.g., the UKGEOS Glasgow site) will provide much of the primary science data on the baseline characteristics of surface and groundwater, soil chemistry, baseline seismicity and engineering geology, as well as on 
resource, replenishment, allowable temperature drop/gain, and any impacts on the environment, to aid appropriate regulation.

\section{ROLE OF TEST SITES IN INTERFACING WITH THE PUBLIC}

The subsurface offers many opportunities to decarbonise the energy system, yet despite widespread societal support of a low carbon future, the subsurface technologies that will enable such a transition are often contested, with recent research identifying a complex mix of values and beliefs, social contexts, and types, scales and locations of technology as drivers that shape attitudes and perceptions (Gibson et al., 2016; Stewart and Lewis, 2017; Dickie et al., 2020; Roberts et al., 2021). It is clear that the success of these emergent underground technologies relies heavily on public acceptance and support-as potential adopters, hosts, consumers and proponents of these technologies.

The planning and development of geo-energy PDPs can provide insights into public awareness, understanding of, and attitudes towards, publicly funded geo-energy science. Dickie et al. (2020) reported on participatory workshops that investigated public awareness, understanding of, and attitudes towards publicly funded geo-energy prompted by the development of the UKGEOS Glasgow site. Amongst participants, high levels of awareness and concern about climate change were demonstrated. However, participants showed much lower levels of knowledge of the distribution and storage components of the energy system and in subsurface contributions to low carbon energy. Workshops revealed four inter-linked themes: those of risk, accountability and trust, and the influence of the media. With much debate around the potential risks involved, many participants felt that they needed more information about the benefits and risks of each of the technologies in order to make more informed decisions.

The Otway test site indicates some of the benefits of site development not only for local engagement and acceptance. A baseline survey of public perception of CCS in the area was carried out towards the end of 2005, with permitting activities taking place in 2007. Otway's local community of Moyne Shire is a dairy farming community with some tourism. Residents had a strong awareness of the land and local environmental issues, and had previous experience with proposals for wind farms and oil and gas exploration. The initial survey found that $33 \%$ of people approved of the project and $38 \%$ showed a degree of discomfort, with safety being the primary concern. The Otway facility developed a communication plan including meetings with local regulators, councils, and businesses, and individual visits to affected landowners. Three large public meetings were held a year with the project manager and CEO of CO2CRC often in attendance, along with technical specialists and research partners from universities. Information was provided in the form of fact sheets, brochures, a project website, and a regular newsletter sent to residents. A community liaison officer was hired from the local area to act as a trusted point of contact with good existing connections (Ashworth et al., 2010). Some problems were encountered by the project during seismic testing, but in general, the project quickly achieved widespread support, helped by its status as a pioneering research initiative and the associated international exposure for the region (Lockwood, 2017).

\section{DISCUSSION}

The value of geo-energy PDPs is in researching rock heterogeneity, fluid flow, and geomechanical and geochemical change, as well as real time monitoring of subsurface changes; all at a scale that is relevant to implementation. They allow geoscientists to take a hypothesis, develop a model, build background laboratorybased concepts, and validate them in field trials, giving a link between concept and "reality." They gather more data on new geo-engineering processes than before and they provide a route from research to commercialisation by testing new innovations and technologies. They allow the probing of risks and problems and allow "fire drills" to deal with low-likelihood but highconsequence events. Because PDPs work with controlled releases and "known" perturbations, the consequences of success or failure are restricted, the lessons are shared, and new knowledge can be iteratively developed through cycles of testing and validation.

Geo-energy PDPs allow an understanding and foundation for appropriate regulation of geo-energy in the subsurface, for example in CCS and geothermal. They may provide a simple "see and feel" experience of geo-energy for stakeholders including government, industry and the public. They work well when the geology of the test site is relevant to geological problems in question, and when initial programs cover baseline atmospheric, soil gas, groundwater, in-reservoir sampling and geophysical monitoring and continue during and after experiments and perturbations. This allows perturbations and changes to be established and understood better.

Geo-energy PDPs are also more effective when open to stakeholders to observe and contribute to the design and development of tests, and the testing and validating of new monitoring tools, and when they widely communicate science both in peer review publications and other publications and outreach.

Sites can be financed and run under a wide range of business models including public-private partnership, public funded and wholly commercial. Business models must employ suitable governance, as well as contingency, liability and risk management. Their operation can give insights into the way that full commercial and operational scale sites might be run, communicating the reality of a new technology, and their work with industry collaborators can provide de-risking and cost saving benefits at the commercial scale.

Successful PDPs involve regulators in the development of the test site itself and in the design of science that will support the regulator in the long term. New regulation will have to allay public concerns, through regulation, that manifestly protects lives, livelihoods and the environment. Research to support 


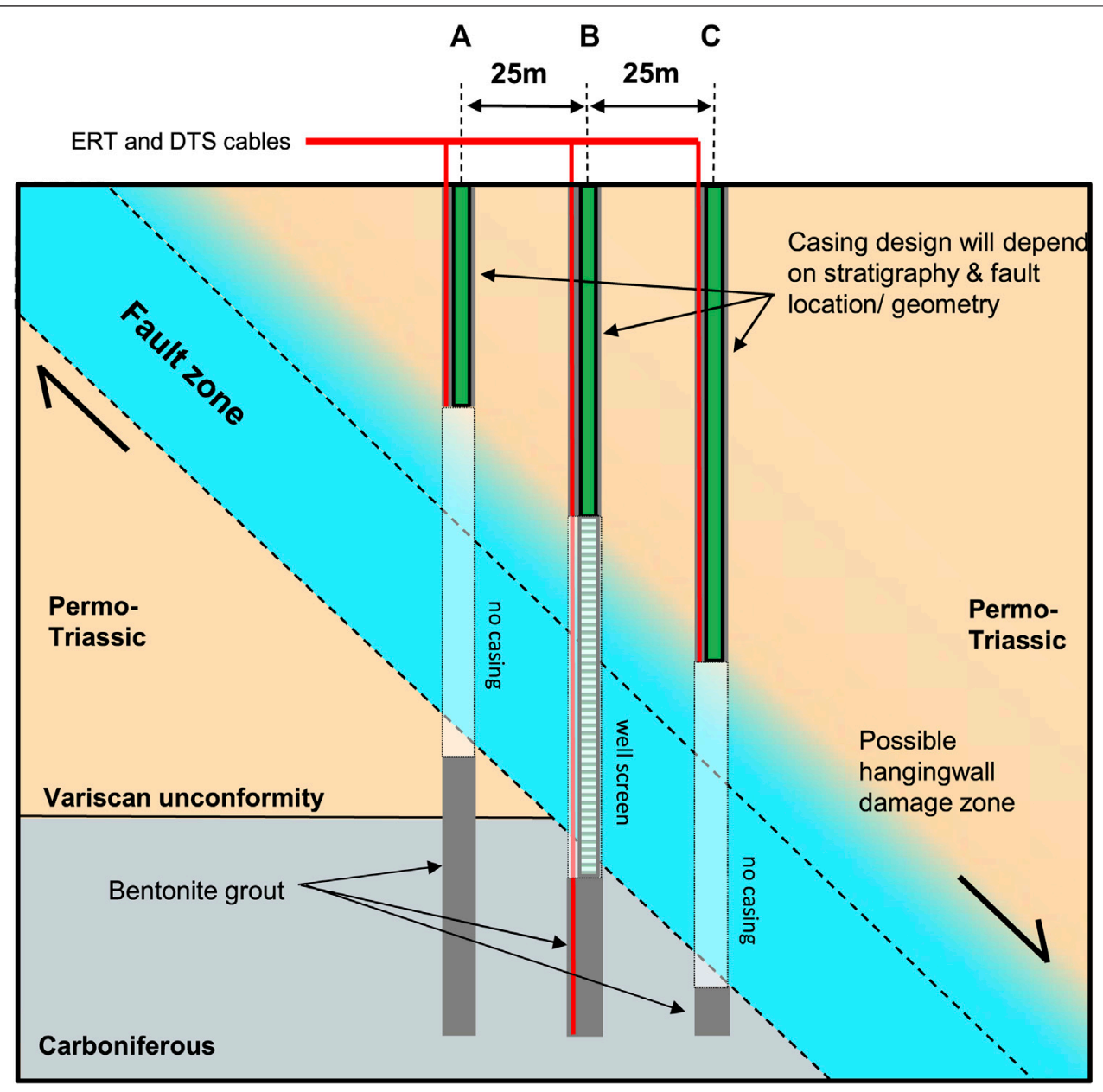

FIGURE 6 | Concept for cross fault borehole array research site.

regulation may involve land use change and the changing subsurface; as well as research into decommissioning (provision, effectiveness, cost and innovation) and the longterm legacy of subsurface energy technology. Regulation will have to deal with multiple uses of the subsurface including potential conflicts in use, cumulative effects and optimising for maximum sustainability. As suggested above, engaging with regulatory bodies in the early stages will help in the translation and adoption of research findings for end users. Overregulation may act as a barrier, not providing the technology developer room to experiment. Also, regulation will have to deal with a mixture of possible commercialisers within the full supply chain of subsurface technology and its linked surface infrastructure (e.g., heat networks, hydrogen transport networks), from SMEs to multinationals.

\section{GAPS IN CAPABILITY IN GEO-ENERGY TEST SITES}

The conference discussion identified two main gaps in the capability and ambition of the present array of PDPs. The first and perhaps most urgent and relates to exploration, implementation, operational monitoring and decommissioning in densely populated urban areas.

It is clear that for some subsurface technologies to be viable, for example low temperature aquifer geothermal and heat/coolth storage, they will have to be operated in densely populated urban areas because low grade heat will not be retained if transported far. How do we design low cost, high resolution, inconspicuous and unobtrusive seismic and other monitoring for a seismically noisy urban environment with a sensitive human population? Subsurface monitoring has to-date mainly been concerned with oil and gas installations but in many low carbon geo-energy technologies monitoring is more difficult than in oil and gas; for example in geothermal, cold/warm water interfaces are harder to detect than oil/gas or gas/ water contacts. PDPs for ATES and coal mine energy are in development, for example the Rijswijk Centre for Sustainable Geo-energy (RCSG) which considers testing of new multilateral drilling techniques known from the oil and gas sector to reduce the footprint of drilling at the surface. The Technical University Delft is developing 
various low cost, inobtrusive monitoring methods. The UKGEOS Glasgow Observatory also aims at novel monitoring techniques such as electrical resistivity tomography. However a range of PDPs researching monitoring techniques for different geologies, for example for urban areas on hard rock as opposed to soft rock, may be appropriate, or PDPs for coastal and inland locations.

The second gap concerns the need for test facilities to analyse the reactivation and transmissivity of faults. The occurrence of faults places extra risks on subsurface technology and development because faults are the locus for seismic events and because faults can both transmit and prevent fluid flow (Faulkner et al., 2010). This has implications for hydrocarbon production and seismicity (e.g., Suckale 2010), geothermal energy production (e.g., Majer et al., 2007), wastewater disposal in depleted reservoirs (Ellsworth 2013) and geological storage of $\mathrm{CO}_{2}$ (Nicol et al., 2011; Burnside et al., 2013), as well as natural gas and hydrogen storage (McMahon et al., 2020).

Although laboratory research and modelling provide valuable knowledge, the following science questions could be addressed at a fault test site: 1 ) investigation of the field-scale properties necessary to evaluate frictional reactivation of the faults (coefficient of friction, shear stress); 2) measurement of at-scale in situ flow properties to provide further insight into the sealing potential of faults (permeability, anisotropy); 3) integration of fault-associated wireline, geological core testing and core scanner data; and 4) investigation of safe drilling and well completion practices within fault zones. These would allow assessments of the properties of faults and how they impact on natural processes such as fluid flow at length scales well beyond those achievable in the lab, and an important test bed for technologies to deal with the hazards posed by faults, such as fluid ingress, induced seismicity, wellbore stability and cross-fault pressure changes. Figure 6 shows a concept for cross fault borehole array research site.

\section{RECOMMENDATIONS AND FURTHER DISCUSSION POINTS}

The conference participants thought that PDPs are generally undervalued in geoscience, in comparison with other disciplines such as physics and astronomy; and especially in view of the fact that due to net zero, there is a pressing need to for geo-energy technologies to be tested in real world conditions. The recommendations and discussion points from the workshop were as follows:

(1) The geo-energy community should first decide on the main science questions and decide what can be carried out at the present set of geo-energy PDPs. Those that cannot be addressed at existing facilities, could if important enough, be the basis for new PDPs, through a clear science plan and funding avenue. Such work will involve forming a more cohesive PDP community, perhaps an alliance, that recognises that many geoscience questions are similar across technologies, for example in relation to compressed air energy storage or hydrogen storage, but also that the community will receive a higher profile with a unified approach.

(2) The configuration of funding and operational support is clearly important with some geo-energy PDPs operating as purely commercial ventures (e.g., Avalon Borehole Test Facility, Rosemanowes Quarry, Penryn), as publicprivate partnerships (e.g., Otway) and as public sector entities (e.g., UKGEOS Glasgow). How can investment be encouraged from the public and private sector? How are the activities likely to be different in geo-energy test sites that are commercially owned and run from those that are entirely publicly owned? How can public-private partnerships be developed for test sites? What business models and governance work best in these three options? How is the balance of CAPEX versus OPEX handled over time? A community of geo-energy PDP scientists or an alliance of existing geo-energy PDPs could set a group to consider these questions. Contributors to the conference suggested that for geo-energy PDPs already in development, alliances could also be established to encourage shared best practice including risk management, joint science and innovation strategies, attempts at data interoperability and international collaboration.

(3) Geoscience platforms exist already that may provide support for test site development. For example EPOS, the European Plate Observing System, is a long-term plan to facilitate integrated use of data, data products, and facilities from distributed research infrastructures for solid Earth science in Europe. EPOS aims mainly at geohazards and geodynamic phenomena relevant to the environment and human welfare, but contains am ambition to facilitate geo-energy infrastructure harmonisation. The European Carbon Dioxide Capture and Storage Laboratory Infrastructure (ECCSEL) was established in June 2017 as a permanent pan-European distributed research infrastructure, ERIC (European Research Infrastructure Consortium). The five European founding member countries (France, Italy, Netherlands, United Kingdom and Norway, offer open access to 79 CCS research facilities across Europe. The Deep-time Digital Earth programme of the International Union of Geological Sciences (Wang et al., 2021) will also provide digital platforms and interoperability tools to support data management and harmonisation. How can existing platforms be used to support experimental field scale science?

(4) Finally it was considered that geo-energy PDPs should be able to learn from exemplars of collaborative science using big infrastructure, for example, astronomy and physics, from the way that science plans are developed, to the way that funding and investment is sought, to governance, and to the ways that test sites work together. 


\section{AUTHOR CONTRIBUTIONS}

MHS, conception, planning and writing; DM, writing; MJS, writing; LS, writing; ZS, writing; AM, writing.

\section{CONFLICT OF INTEREST}

MHS was employed by the company Stephenson Geoscience Consulting for part of the work.

\section{REFERENCES}

Abesser, C., Schofield, D. I., Busby, J., and Bonsor, H. (2018). Who Owns (Geothermal) Heat? British Geological Survey Science Briefing Paper, Available at:

Alfredsson, H. A., Oelkers, E. H., Hardarsson, B. S., Franzson, H., Gunnlaugsson, E., and Gislason, S. R. (2013). The Geology and Water Chemistry of the Hellisheidi, SW-Iceland Carbon Storage Site. Int. J. Greenhouse Gas Control. 12, 399-418. doi:10.1016/j. ijggc.2012.11.019

Árnason, K. (2020). New Conceptual Model for the MagmaHydrothermal-Tectonic System of Krafla, NE Iceland. Geosciences 10 (1), 34. doi:10.3390/geosciences 10010034

Ashworth, P., Bradbury, J., Feenstra, C. F. J., Greenberg, S., Hund, G., Mikunda, T., et al. (2010). Communication, Project Planning and Management for Carbon Capture and Storage Projects: An International Comparison. EP 104273. Australia. Commonwealth Scientific and Industrial Research Organisation, 221.

Banks, D., Fraga Pumar, A., and Watson, I. (2009). The Operational Performance of Scottish Minewater-Based Ground Source Heat Pump Systems. Q. J. Eng. Geology. Hydrogeology 42, 347-357. doi:10.1144/1470-9236/08-081

Banks, D., Athresh, A., Al-Habaibeh, A., and Burnside, N. (2017). Water from Abandoned Mines as a Heat Source: Practical Experiences of Open- and Closed-Loop Strategies, United Kingdom. Sustain. Water Resour. Manag. 5, 29-50. doi:10.1007/s40899-017-0094-7

Barrow Island Act (2003). Barrow Island Act. Available at: https:// www.legislation.wa.gov.au/legislation/statutes.nsf/main_mrtitle_ 76_homepage.html (Accessed 6 22, 2021).

Bickle, M. J., Stevenson, E. I., and Haese, R. R. (2020). Sr-isotopic Ratios Trace Mixing and Dispersion in CO2 Push-Pull Injection Experiments at the CO2CRC Otway Research Facility, Australia. Chem. Geology. 538, 119489. doi:10.1016/j.chemgeo.2020.119489

Brabham, P., ManjuThomas, M., Thomas, H., Farr, G., Francis, R., Sahid, R., et al. (2019). The Potential Use of Mine Water for a District Heating Scheme at Caerau, Upper Llynfi valley, South Wales, UK. Q. J. Eng. Geology. Hydrogeology 53, 145-158. doi:10.1144/ qjegh2018-213

Burnside, N. M., Shipton, Z. K., Dockrill, B., and Ellam, R. M. (2013). Manmade versus Natural CO2 Leakage: A 400 k.Y. History of an Analogue for Engineered Geological Storage of CO2. Geology 41, 471-474. doi:10.1130/G33738.1

Burnside, N. M., Banks, D., and Boyce, A. J. (2016a). Sustainability of thermal Energy Production at the Flooded Mine Workings of the Former Caphouse Colliery, Yorkshire, United Kingdom. Int. J. Coal Geology. 164, 85-91. doi:10.1016/j.coal.2016.03.006

Burnside, N. M., Banks, D., Boyce, A. J., and Athresh, A. (2016b). Hydrochemistry and Stable Isotopes as Tools for Understanding the Sustainability of Minewater Geothermal Energy Production from a 'standing Column' Heat Pump System: Markham Colliery, Bolsover, Derbyshire, UK. Int. J. Coal Geology. 165, 223-230. doi:10.1016/j.coal.2016.08.021
The remaining authors declare that the research was conducted in the absence of any commercial or financial relationships that could be construed as a potential conflict of interest.

\section{ACKNOWLEDGMENTS}

Thanks to Becky Goddard of the Geological Society for helping to organise the conference, and the Director of the British Geological Survey for permission to publish.

Climate Change Committee(2018). CCC Welcomes Government's Recommitment to Carbon Capture and Storage Technology Climate Change Committee (theccc.org.uk).

Cook, P. J. (2014). Geologically Storing Carbon: Learning from the Otway Project Experience. CSIRO Publishing.

Cuss, R. J., Harrington, J. F., Noy, D. J., Wikman, A., and Sellin, P. (2011). Large Scale Gas Injection Test (Lasgit): Results from Two Gas Injection Tests. Phys. Chem. Earth, Parts A/B/C 36, 1729-1742. ISSN 1474-7065. doi:10.1016/j.pce.2011.07.022

Cuss, R. J., Harrington, J. F., NoyGraham, D. J. C. C., Graham, C. C., and Sellin, P. (2014). Evidence of Localised Gas Propagation Pathways in a Field-Scale Bentonite Engineered Barrier System; Results from Three Gas Injection Tests in the Large Scale Gas Injection Test (Lasgit). Appl. Clay Sci. 102, 81-92. ISSN 0169-1317. doi:10.1016/j. clay.2014.10.014

Dickie, J., Watson, E., and Napier, H. (2020). Evaluating the Relationship between Public Perception, Engagement and Attitudes towards Underground Energy technologiesBGS Report Open Report OR/20/056.

Downey, F. (20122012). Response to the House of Commons Science and Technology Select Committee Bridging the "valley of Death": Improving the Commercialisation of Research Inquiry from Engineering the Future. The Royal Academy of Engineering.

Ellsworth, W. L. (2013). Injection-Induced Earthquakes. Science 341, 1225942. doi:10.1126/science. 1225942

Energy Transitions Commission (20172017). Better Energy. Greater Prosperity.

European Commission (2020). Final Report Summary - HELIX (HighEnd cLimate Impacts and eXtremes). Available at: https://cordis. europa.eu/project/id/603864/reporting (accessed 12 07, 2020).

Evans, D., Stephenson, M. H., and Shaw, R. P. (2009). The Use of Britain's Subsurface. Land Use Policy 134, 34-58.

Evans, D. (2008). An Appraisal of Underground Gas Storage Technologies and Incidents, for the Development of Risk Assessment methodologyReport by the British Geological Survey to the Health \& Safety Executive (HSE), HSE Research Report Series. Number RR605 Available at: http://www.hse.gov.uk/research/ rrpdf/rr605.pdf. 350pp.

Farr, G., Sadasivam, S., ManjuWatson, I. A., Watson, I. A., Thomas, H. R., and Tucker, D. (2016). Low Enthalpy Heat Recovery Potential from Coal Mine Discharges in the South Wales Coalfield. Int. J. Coal Geology. 164, 92-103. doi:10.1016/j.coal.2016.05.008

Farr, G., Busby, J., Wyatt, L., Crooks, J., Schofield, D. I., and Holden, A. (2020). The Temperature of Britain's Coalfields. Q. J. Eng. Geology. Hydrogeology 54, qjegh2020-109. doi:10.1144/qjegh2020-109

Faulkner, D. R., Jackson, C. A. L., Lunn, R. J., Schlische, R. W., Shipton, Z. K., Wibberley, C. A. J., et al. (2010). A Review of Recent Developments Concerning the Structure, Mechanics and Fluid Flow Properties of Fault Zones. J. Struct. Geology. 32, 1557-1575. doi:10.1016/j.jsg.2010.06.009

Gibson, H., Stewart, I. S., Pahl, S., and Stokes, A. (20162016). A "mental Models" Approach to the Communication of Subsurface Hydrology and Hazards. Hydrol. Earth Syst. Sci. 20, 1737-1749. doi:10.5194/ hess-20-1737-2016 
Graham, C. C., Harrington, J. F., Cuss, R. J., and Sellin, P. (2012). Gas Migration Experiments in Bentonite: Implications for Numerical Modelling. Mineral. Mag. 76, 3279-3292. doi:10.1180/minmag. 2012.076.8.41

Griffioen, J., van Wensem, J., Oomes, J. L. M., Barends, F., Breunese, J., Bruining, H., et al. (2014). A Technical Investigation on Tools and Concepts for Sustainable Management of the Subsurface in The Netherlands. Sci. Total Environ. 485-486, 810-819. ISSN 0048-9697. doi:10.1016/j.scitotenv.2014.02.114

Harnmeijer, J., Schlicke, A., Barron, H., Banks, D., Townsend, D., Steen, P., et al. (2012). Fortissat Minewater Geothermal District Heating Project: Case Study. Eng. Tech. Reference 1, 1-8. doi:10.1049/etr. 2016.0087

Havercroft, I., and Consoli, C. (2018). Global CCS Institute Thought Leadership Report, the Carbon Capture and Storage Readiness Index 2018, Is the World Ready for Carbon Capture and Storage. Available at: https://www.globalccsinstitute.com/archive/hub/ publications/202108/ccs-readiness-index-2018global-ccs-institute2018digital.pdf (Accessed 6 22, 2021).

Hellsmark, H., Frishammar, J., Söderholm, P., and Ylinenpää, H. (2016). The Role of Pilot and Demonstration Plants in Technology Development and Innovation Policy. Res. Pol. 45, 1743-1761. ISSN 0048-7333. doi:10.1016/j.respol.2016.05.005

Holloway, S. (2007). Carbon Dioxide Capture and Geological Storage. Phil. Trans. R. Soc. A. 365, 1095-1107. doi:10.1098/ rsta.2006.1953

Intergovernmental Panel on Climate Change (2018). "Summary for Policymakers," in Global Warming of $1.5^{\circ} \mathrm{C}$. An IPCC Special Report on the Impacts of Global Warming of $1.5^{\circ} \mathrm{C}$ above Preindustrial Levels and Related Global Greenhouse Gas Emission Pathways, in the Context of Strengthening the Global Response to the Threat of Climate Change, Sustainable Development, and Efforts to Eradicate Poverty. Editor V. Masson-Delmotte, et al. (Geneva, Switzerland: World Meteorological Organization).

Intergovernmental Panel on Climate Change (2019). Chapter 4Executive Summary. Special Report on the Ocean and Cryosphere in a Changing Climate Summary for Policymakers.

International Energy Agency (2018). World Energy Outlook, 714.

Jenkins, C. R., Cook, P. J., Ennis-King, J., Undershultz, J., Boreham, C., Dance, T., et al. (2012). Safe Storage and Effective Monitoring of CO2 in Depleted Gas fields. Proc. Natl. Acad. Sci. 109, E35-E41. doi:10.1073/pnas. 1107255108

Lanchester Wines website (2021) Lanchester Wines Website. Available at: https://www.lanchesterwines.co.uk/what-we-do/sustainability/ (Accessed May 2021)

Leeds City Gate (2019). Leeds City Gate. Available at: https://www. northerngasnetworks.co.uk/wp-content/uploads/2017/04/H21Report-Interactive-PDF-July-2016.compressed.pdf.

Lockwood, T. (2017). Public Outreach Approaches for Carbon Capture and Storage Projects. IEA Clean Coal Centre.

Loredo, C., Ordóñez, A., Garcia-Ordiales, E., Álvarez, R., Roqueñi, N., Cienfuegos, P., et al. (2017). Hydrochemical Characterization of a Mine Water Geothermal Energy Resource in NW Spain. Sci. Total Environ. 576, 59-69. doi:10.1016/j.scitotenv.2016.10.084

Loveless, S. E., Bloomfield, J. P., Ward, R. S., Hart, A. J., Davey, I. R., and Lewis, M. A. (2018). Characterising the Vertical Separation of ShaleGas Source Rocks and Aquifers across England and Wales (UK). Hydrogeol J. 26, 1975-1987. doi:10.1007/s10040-018-1737-y

Ma, J., Li, Q., Kühn, M., and Nakaten, N. (2018). Power-to-gas Based Subsurface Energy Storage: A Review. Renew. Sustain. Energ. Rev. 97, 478-496. doi:10.1016/j.rser.2018.08.056

Majer, E. L., Baria, R., Stark, M., Oates, S., Bommer, J., Smith, B., et al. (2007). Induced Seismicity Associated with Enhanced Geothermal Systems. Geothermics 36, 185-222. doi:10.1016/j.geothermics. 2007.03.003

Major, M., Poulsen, S. E., and Balling, N. (2018). A Numerical Investigation of Combined Heat Storage and Extraction in Deep
Geothermal Reservoirs. Geotherm Energy 6, 1. doi:10.1186/s40517018-0089-0

Masanet, E., Shehabi, A., Lei, N., Smith, S., and Koomey, J. (2020). Recalibrating Global Data center Energy-Use Estimates. Science 367 (6481), 984-986. doi:10.1126/science.aba3758

McCay, A. T., Feliks, M. E. J., and Roberts, J. J. (2019). Life Cycle Assessment of the Carbon Intensity of Deep Geothermal Heat Systems: A Case Study from Scotland. Sci. Total Environ. 685, 208-219. doi:10.1016/j.scitotenv.2019.05.311

McEvoy, F. M., Schofield, D. I., Shaw, R. P., and Norris, S. (2016). Tectonic and Climatic Considerations for Deep Geological Disposal of Radioactive Waste: A UK Perspective. Sci. Total Environ. 571, 507-521. doi:10.1016/j.scitotenv.2016.07.018

McMahon, C. J., Roberts, J. J., Johnson, G., Shipton, Z. K., and Edlmann, K. (2020). "Geological Storage of Hydrogen: Learning from Natural Analogues," in EGU General Assembly Conference Abstracts EGU2020-18548. doi:10.5194/egusphere-egu2020-18548

Monaghan, A. A., O'Dochartaigh, B., Fordyce, F., Loveless, S., Entwisle, D., Quinn, M., et al. (2017a). UKGEOS: Glasgow Geothermal Energy Research Field Site (GGERFS): Initial Summary of the Geological Platform. Nottingham, UK: British Geological Survey Open Report. OR/17/006. http://nora.nerc.ac.uk/id/eprint/518636/.

Monaghan, A. A., Starcher, V., Ó Dochartaigh, B. E., Shorter, K. M., and Burkin, J. (2019). UK Geoenergy Observatories: Glasgow Geothermal Energy Research Field Site: Science Infrastructure Version 2British Geological Survey Open Report. OR/19/032, Available at: http://nora.nerc.ac.uk/id/eprint/522814/.

Monaghan, A. A., Starcher, V., Barron, H. F., Shorter, K., Walker-Verkuil, K., Elsome, J., et al. (2021). Drilling into Mines for Heat: Geological Synthesis of the UK Geoenergy Observatory in Glasgow and Implications for Mine Water Heat Resources. Q. J. Eng. Geology. Hydrogeology, qjegh2021-033. doi:10.1144/qjegh2021-033

Monaghan, A. A. (2017b). Unconventional Energy Resources in a Crowded Subsurface: Reducing Uncertainty and Developing a Separation Zone Concept for Resource Estimation and Deep 3D Subsurface Planning Using Legacy Mining Data. Sci. Total Environ. 601-602, 45-56. doi:10.1016/j.scitotenv.2017.05.125

Naumann, G., Alfieri, L., Wyser, K., Mentaschi, L., Betts, R. A., Carrao, H., et al. (2018). Global Changes in Drought Conditions under Different Levels of Warming. Geophys. Res. Lett. 45, 3285-3296. doi:10.1002/ 2017GL076521

Nicol, A., Carne, R., Gerstenberger, M., and Christophersen, A. (2011). Induced Seismicity and its Implications for $\mathrm{CO} 2$ Storage Risk. Energ. Proced. 4, 3699-3706. doi:10.1016/j.egypro.2011.02.302

Obringer, R., Rachunok, B., Maia-Silva, D., Arbabzadeh, M., Nateghi, R., and Madani, K. (2021). The Overlooked Environmental Footprint of Increasing Internet Use. Resour. Conservation Recycling 167, 105389. doi:10.1016/j.resconrec.2020.105389

Pacala, S., and Socolow, R. (2004). Stabilization Wedges: Solving the Climate Problem for the Next 50 Years with Current Technologies. Science 305, 968-972. doi:10.1126/science. 1100103

Paterson, L., Boreham, C., Bunch, M., Dance, T., Ennis-King, J., Freifeld, B., et al. (2013). Overview of the CO2CRC Otway Residual Saturation and Dissolution Test. Energ. Proced. 37, 6140-6148. doi:10.1016/j. egypro.2013.06.543

Phelps, J. J. C., Blackford, J. C., Holt, J. T., and Polton, J. A. (2015). Modelling Large-Scale CO 2 Leakages in the North Sea. Int. J. Greenhouse Gas Control. 38, 210-220. doi:10.1016/j.ijggc.2014.10.013

Preene, M., and Younger, P. L. (2014). Can You Take the Heat? Geothermal Energy in Mining. Mining Tech. 123, 107-118. doi:10. 1179/1743286314Y.0000000058

Roberts, J. J., Bond, C. E., and Shipton, Z. K. (2021). Fracking Bad Language: Hydraulic Fracturing and Earthquake Risk. Geosci. Commun. 4, 1-25. doi:10.5194/gc-4-1-2021

Rockström, J., Gaffney, O., Rogelj, J., Meinshausen, M., Nakicenovic, N., and Schellnhuber, H. (2017). A Roadmap for Rapid Decarbonisation. Science 355, 1269-1271. 
Slater, T., Hogg, A. E., and Mottram, R. (2020). Ice-Sheet Losses Track High-End Sea-Level Rise Projections. Nat. Clim. Chang. 10, 879-881. doi:10.1038/s41558-020-0893-y

Steckel, J. C., Brecha, R. J., Jakob, M., Strefler, J., and Luderer, G. (2013). Development without Energy? Assessing Future Scenarios of Energy Consumption in Developing Countries. Ecol. Econ. 90, 53-67. doi:10. 1016/j.ecolecon.2013.02.006

Stephenson, M. H., Ringrose, P., Geiger, S., Bridden, M., and Schofield, D. (2019). Geoscience and Decarbonization: Current Status and Future Directions. Pet. Geosci. 25, 501-508. doi:10.1144/petgeo2019-084

Stephenson, M. H. (2013). Returning Carbon to Nature; Coal, Carbon Capture, and Storage Elsevier. Amsterdam 143, 51-6196. doi:10. 5860/choice.51-6196

Stephenson, M. H. (2018). Energy and Climate Change: An Introduction to Geological Controls, Interventions and Mitigations' Elsevier. Amsterdam 186, 175-178. doi:10.1016/b978-0-12-812021-7.00009-9

Stephenson, M. H. (2021). "Affordable and Clean Energy," in Geosciences and the Sustainable Development Goals. Sustainable Development Goals Series. Editors J. C. Gill and M. Smith (Springer). doi:10.1007/978-3-030-38815-7_7

Stewart, I. S., and Lewis, D. (20172017). Communicating Contested Geoscience to the Public: Moving from 'matters of Fact' to 'matters of Concern. Earth-Science Rev. 174, 122-133. doi:10.1016/j. earscirev.2017.09.003

Stober, I., and Bucher, K. (2021). Geothermal Energy from Theoretical Models to Exploration and Development. Springer 390pp.

Suckale, J. (2010). Moderate-to-large Seismicity Induced by Hydrocarbon Production. The Leading Edge 29, 310-319.

The Commonwealth Offshore Petroleum and Greenhouse Gas Storage Act 2006 The Commonwealth Offshore Petroleum and Greenhouse Gas Storage Act Available at: https://www.legislation.gov.au/ Details/C2021C00053 Accessed 22/6/2020

Todd, F., McDermott, C., Harris, A. F., Bond, A., and Gilfillan, S. (2019). Coupled Hydraulic and Mechanical Model of Surface Uplift Due to Mine Water Rebound: Implications for Mine Water Heating and Cooling Schemes. Scottish J. Geology. 55, 124-133. doi:10.1144/ sjg2018

Townsend, D., Naismith, J. D. A., Townsend, P. J., Milner, M. G., and Fraser, U. T. (2020). "'On the Rocks' - Exploring Business Models for
Geothermal Heat in the Land of Scotch," in Proceedings World Geothermal Congress 2020 (Reykjavik, Iceland. .

UKCCS Research Centre website (2021) UKCCS Research Centre Website Available at: https://ukccsrc.ac.uk/ccs-explained/

UN Environment Programme (2019). Emissions Gap Report 2019. Available at: https://www.unenvironment.org/resources/ emissions-gap-report-2019.

Verhoeven, R., Willems, E., Harcouët-Menou, V., De Boever, E., Hiddes, L., Op'T Veld, P., et al. (2014). Minewater 2.0 Project in Heerlen the Netherlands: Transformation of a Geothermal Mine Water Pilot Project into a Full Scale Hybrid Sustainable Energy Infrastructure for Heating and Cooling. Energ. Proced. 46, 58-67. doi:10.1016/j.egypro.2014.01.158

Victorian Greenhouse Gas Geological Sequestration Act (2008). Victorian Greenhouse Gas Geological Sequestration Act. Available at: https://www.legislation.vic.gov.au/in-force/acts/ greenhouse-gas-geological-sequestration-act-2008/013 (Accessed $622,2021)$.

Victorian Offshore Petroleum and Greenhouse Gas Storage Act (2010). Victorian Offshore Petroleum and Greenhouse Gas Storage Act. Available at: https://www.legislation.vic.gov.au/ in-force/acts/offshore-petroleum-and-greenhouse-gas-storageact-2010 (Accessed 226, 2021).

Wang, C., Hazen, R. M., Cheng, Q., Stephenson, M. H., Zhou, C., Fox, P., et al. (2021). The Deep-Time Digital Earth Program: Data-Driven Discovery in Geosciences. Natl. Sci. Rev. doi:10.1093/nsr/nwab027

Western Australia Petroleum and Geothermal Energy Resources Act Western Australia Petroleum and Geothermal Energy Resources Act (1967) Available at: https://www.legislation.wa.gov.au/legislation/ statutes.nsf/main_mrtitle_704_homepage.html (Accessed 22/6/ 2021)

Copyright (๑) 2022 Stephenson, Manning, Spence, Stalker, Shipton and Monaghan. This is an open-access article distributed under the terms of the Creative Commons Attribution License (CC BY). The use, distribution or reproduction in other forums is permitted, provided the original author(s) and the copyright owner(s) are credited and that the original publication in this journal is cited, in accordance with accepted academic practice. No use, distribution or reproduction is permitted which does not comply with these terms. 